\title{
ECONOMIC SHOCKS ON PARTNERS' TRADE; AFRICA AND ASEAN ON CHINA
}

\author{
Emmanuel Yamoah Cobbold ${ }^{1}$ \\ ${ }^{1}$ School of Finance and Economics, Jiangsu University, Zhenjiang, Jiangsu province, China
}

\author{
Dan Owusu ${ }^{2}$ \\ ${ }^{2}$ School of Finance and Economics, Jiangsu University, Zhenjiang, Jiangsu province, China
}

Article DOI: https://doi.org/10.36713/epra5519

\begin{abstract}
This research studies the impact of macroeconomic shocks from African and the Association of Southeast Asian Nations (ASEAN) on China's bilateral trade with them. Data on (GDP) per capita, FDI, inflation, unemployment rates, and trade openness (TO) of China's African and ASEAN partners were sourced from the World Bank whilst imports and exports data were from the world integrated trade solutions (WITS). It uses the gravity model as a basis and the panel corrected standard errors (PCSE) as well as multivariate regression estimators.

The findings reveal that per capita of China's partners have a strong positive impact on trade with them. Trade openness is reported to increase China's imports but reduce exports to these partners. Further, an increase in FDI inflows to China's trade partners leads to an increase in both imports and exports of China.
\end{abstract}

KEYWORDS: Economic shocks, international trade, China, Africa, ASEAN, gravity model JEL classifications: F4; F69; C13; C23

\section{INTRODUCTION}

With the current number of research on international trade and economic growth, the discussion seems sealed on the fact the trade with other countries causes a spike in a country's economic growth and welfare. Opening up an economy to trade allows it to access the wider international market and at the same time, permit international traders to also have access to the local market. This certainly presents opportunities and risks. A country's international trade policies and strategies could affect every aspect of the economy. This is easily possible due to the interconnectivity of sectors of the economy.

Empirical results mostly point that, in the long run, more outward-oriented economies see better economic growth. Studies including (Frankel \& Romer, 1999; Sachs \& Warner, 1995; Chang et al., 2009) conclude that trade openness is a better influencer of growth. The findings of (Huchet-bourdon et al., 2018) bring into the equation, a new thing; product quality. In their study, they found statistical backings to support the assertion that trade may impact growth negatively for countries that have specialized in low-quality products. Further, studies by (Vamvakidis, 2002) and others found no evidence to support this claim whilst (Moyo \& Khobai, 2018; Vlastou, 2010) conclude that economic growth has no bearing with trade openness. Trade openness exposes an economy to the sweetness and bitter of the international environment.

Economies, industries, and firms have developed strong ties with partners within or out of 


\section{SJIF Impact Factor 2021: 7.13| ISI I.F.Value:1.241| Journal DOI: 10.36713/epra2016 \\ ISSN: 2455-7838(Online) \\ EPRA International Journal of Research and Development (IJRD)}

Volume: 6 | Issue: 3 | March 2021

- Peer Reviewed Journal

their continent. In the last decade, macroeconomic shocks at the international level have been quantitatively very relevant due to globalization. The well-being of economies is much interlinked than before. As asserted by (Easterly \& Kraay, 1999), the most integrated economies of the world are most likely to experience shocks from partners.

Today's globalization of economies is largely attributed to the rapid evolution of science and technology which has been felt in all aspects of every economy. Economic globalization has impacted trade from several angles. Companies and industries are also exposed to a wide range of alternative competitive input sources and access to labor at competitive rates.

The regions of Africa and Asia have taken solid ground in international trade and seen rapid economic growth in the past decades. According to (OECD, 2015 ), the US economy grew by $1.6 \%$, the EU by $1.7 \%$, Latin America by $4.6 \%$, and Asia by $5.9 \%$ resulting in a substantial increase in the regional share of Asia on the world GDP. With a growth rate of 3.2 percent in 2018, Africa's growth rate was projected to rise to 3.4 in 2019 and to 3.7 in 2020 (UN, 2019). Both regions continue to show prospects for outstanding economic performances.

As pointed by researchers including (Savrul \& Onsekiz, 2015), globalization has a significant impact on international trade. Despite the many benefit of globalization, it has also been observed to have negative impacts including job security (the case of NAFTA), labor remunerations, inflation, migration, terrorism, and others. The wave of globalization is present in every aspect of an economy including education (Tight, 2019; Webb et al., 2006), finance (Huang, 2020; Tarim, 2010), health (Briggs et al.,
2020; Dunford \& Qi, 2020) and other aspects of the world economy.

Sectors of an economy are also linked and dependent on each other. A change in a major sector of an economy has the potential to affect all other aspects of the economy. This is referred to as an economic shock. Financial shocks such as changes in monetary or fiscal policies affect industries and individual homes in the long run. Mostly in Africa, changes in energy prices are felt across all sectors as well as individual homes. An economic shock could arise from within a country or from its allied economies.

Today, the economic progress or otherwise of a country has a bearing on its global partners. Developing economies have often been at the receiving end of these shocks stemming from the recent opening of these economies to international trade. The ability of an economy to stand these external unpredictable "economic events" depends on strong macroeconomic foundations and management.

\section{China-Africa Trade}

Africa's trade with China has seen a boost in recent years reaching $\$ 42.94$ billion in 2017 (Chen et al., 2020). (Nowak, 2016) reveal that Sino-African trade between 2000 and 2014 increase by about 21 times. China launched the Grand Plan of Trade and Economic Cooperation in 1994 as well as the ExportImport (EXIM) Bank of China to provide concessional loans to support the development of China's foreign trade (Nowak, 2015). Between 2000 and 2018, Chinese loans to Africa was valued at $\$ 148$ billion (Brautigam et al., 2020). However, finding on the destination countries of Sino-Africa loans by (Locke \& Aguiar, 2018) reveals that the greater part of these loans goes to the advanced African economies.

Figure 1: Sino-Africa trade

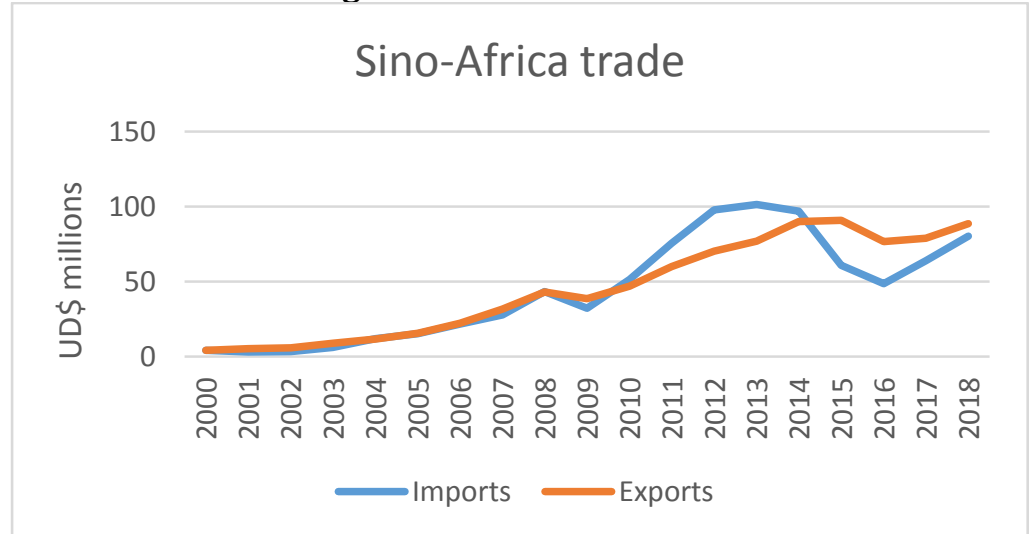

Note: The figure consists of trade data between China and the African countries in this paper only. 


\section{SJIF Impact Factor 2021: 7.13| ISI I.F.Value:1.241| Journal DOI: 10.36713/epra2016 \\ ISSN: 2455-7838(Online) \\ EPRA International Journal of Research and Development (IJRD)}

With an export volume of about $\$ 105$ billion as of 2018, China's trade ties with the continent continue to strengthen. Africa's export to China has also seen an increase in the same direction. This can partly be attributed to the presence of the economic ties between the two parties and also that African countries are improving upon the nature of their exports, i.e. from raw materials to semi and finished products.

\section{China-ASEAN trade}

The Association of Southeast Asian Nations (ASEAN) which succeeded the Association of Southeast Asia (ASA) was formed by Indonesia, the Philippines, Malaysia, Singapore, and Thailand in 1967 (ASEAN, 2016). Brunei joined the group in 1984, Vietnam in 1995 whilst other countries such as Laos, Myanmar, and Cambodia later joined. The world's largest Free Trade Agreement (FTA) by population; the ASEAN-China FTA remains an important commitment to both signatories. It came into effect in January 2010 with zero tariffs for $93 \%$ of traded products (Flick \& Kemburi, 2012). During the first quarter of 2020, the region took over the EU to become China's biggest trading partner attracting 15\% of China's total trade (Medina, 2020).

Figure 2: Sino-ASEAN trade

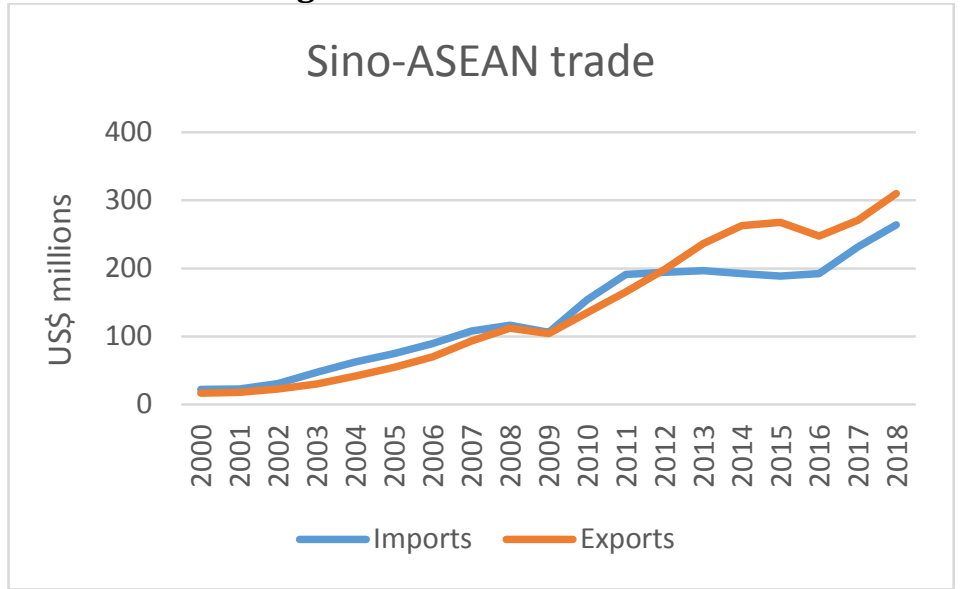

Note: The figure consists of trade data between China and the ASEAN countries in this paper only.

The economic relations between Africa and China have been measured from several economic and political viewpoints (Adekunle \& Monika, 2017; Baliamoune-Lutz, 2011; Large, 2008; Obuah \& Alabama, 2012) whilst that of China-ASEAN has equally gotten some attention. Most of these studies are channeled at the wins and losses and measures to boost trade. This paper takes a complete turn from these. Considering the current rise of African and ASEAN economies as well as their trade with China, this paper seeks to measure how fluctuations in their macroeconomics disturb or otherwise China's trade with them.

\section{LITERATURE REVIEW}

Several studies have explained how some key macroeconomic indicators affect a country's international trade patterns. Issues regarding inflation and exchange rates, as well as unemployment and some indicators have been empirically pointed to have different impacts on a country's international trade. How open an economy is in terms of trade has also been revealed to make it vulnerable to international macroeconomics.

It is asserted that trade openness leads to greater economic efficiency. However, factors such as technological advancement, government policies, and factors peculiar to individual economies could result in different outcomes for various economies.

Trade openness has been found to expose an economy to risk from the international economy as well as shocks from trade and economic partners. In a review of the correlation between trade openness and economic growth between 1990 and 2016, (Moyo \& Khobai, 2018) tested data of members of the Southern African Development Cooperation (SADC). In their analysis employing the ARDL-bounds test approach and the Pooled Mean Group (PMG) model, they discovered that trade openness harms the economic growth of these countries in the long-run.

In a related one on the 10 Central-Eastern European Economies (CEECs-10), (Silajdzic \& Mehic, 2018) found robust evidence that trade intensity measures are positively associated with economic 


\section{SJIF Impact Factor 2021: 7.13| ISI I.F.Value:1.241| Journal DOI: 10.36713/epra2016 \\ ISSN: 2455-7838(Online) \\ EPRA International Journal of Research and Development (IJRD)}

Volume: 6 | Issue: 3 | March 2021

- Peer Reviewed Journal

growth. Their study applied the panel corrected standard errors (PCSE) on data on GDP per capita, applied tariff rate, trade openness, government expenditure, and domestic investment. Again, using the Cobb-Douglas production function and the alternative panel estimators on 38 countries between 1980 and 2008, (Yeboah et al., 2012) revealed a positive relationship to exist between gross domestic product (GDP).

An interesting revelation was made in (Nduka et al., 2013) similar to that of (Olufemi, 2004) where the results showed a mixed outcome of the opennessgrowth phenomenon. In studying the Nigerian economy, Olufemi's conclusions suggested that the country's benefit or otherwise from openness is reliant on the prevailing level of economic development. In Nduka et al., it was found that economic growth leads to opening the economy to international trade, which again leads to more economic growth. However, in studying 2 top West African countries; Nigeria and Ghana, (Khobai et al., 2018) provide evidence to support that openness impacts differently on various economies. Using data from 1980 and 2016 and the autoregressive distributed lag model, their results indicated that trade openness has a strong positive impact on Ghana's economic but an insignificant negative impact on Nigeria.

Studies on trade openness have drawn attention to the possibility of an economy being impacted by its partners. In examining the impact of trade liberalization on growth, (Ben-David, 1993) found a strong link between the timing of trade reform (trade liberalization) and income convergence amongst the six European Economic Community (EEC) members employed in his study. Further, in a research into the relationship between growth and poverty, (Dollar \& Kraay, 2004) came with evidence to support the argument that openness of an economy reduces poverty rates.

Specifically, on ECOWAS economies, more insight was seen in (Bello \& Akinbobola, 2020). Their study analyzed data on poverty (proxy by consumption expenditure per capita), trade openness, GDP, government expenditure, financial deepening (proxy by the ratio of domestic private credit as a percentage of GDP) as well as the inflation rate of 9 economies from 1986 and 2015. Haven employed the Panel Error Correction Model (PECM), it was indicated that a bidirectional causality exists between trade openness and poverty and a further uni-directional causality between economic growth and poverty.

As economies open up and intensify their integration into the global economy, they become interdependent. The developed economies depend on the developing partners (who mostly have essential industry raw materials) to keep their industries operational. By this interdependence, countries expose themselves to potential shock that may arise from their partners. The magnitude of the shock however would depend on the degree of interdependence amongst them.

(Montalbano et al., 2005) found a linkage between trade openness and economic growth of Eastern European Countries (EECs). They established that trade shocks caused adverse impacts on these economies in the early 1990s. Inspired by (Ligon, 2003), their approach defines the vulnerability of an economy as the difference between the expected per capita consumption growth under the hypothesis of no shocks and the expected value of the same variable under the hypothesis of shocks. Substantive evidence of the openness-GDP and openness-volatility relationship was revealed in (Yin et al., 2018). In a counterfactual analysis on Macau, they found that the Closer Economic Partnership Arrangement (CEPA) between Mainland and Macau increased the annual real GDP growth rate of Macau by $20.76 \%$ from 2004 to 2007, meanwhile it increased the volatility of real GDP growth rate by $35 \%$. This implies that openness is indeed a good way to attain economic growth just that it requires strong economic management so that its negative impacts (shocks) do no turn around to harm the economy just as the views of (Federici \& Montalbano, 2010). Other studies such as (Guillaumont, 2000; Montalbano, 2016) provide substantive theoretical and empirical discussions on trade openness and vulnerability.

Answers as to how a country could remain open to the "international-country" but mitigate the risk of volatility and economic shocks are specified in (Haddad et al., 2013) who argue that positive thresholds for product diversification at which the effect of openness on volatility shows different results. They point that the effect shows positive only for countries with highly concentrated export baskets, thus having diversified exports helps reduce the possible impacts of vulnerability and shocks.

African economies have not been spared in international economic shocks. In measuring the experience of sub-Saharan economies with external shocks between 1979 and 1978, the approach of (Balassa, 1983) classified the study countries into lower and middle-income countries. Key amongst the findings was that losses in export shares and the extent of import substitution were lesser in the oil-importing middle-income countries. This supports the discussion that the impact of an economic shock could differ depending on the "trade strength" of the economy. 


\section{SJIF Impact Factor 2021: 7.13| ISI I.F.Value:1.241| Journal DOI: 10.36713/epra2016 \\ ISSN: 2455-7838(Online) \\ EPRA International Journal of Research and Development (IJRD)}

Volume: 6 | Issue: 3 | March 2021

- Peer Reviewed Journal

In studying the main channels through which international economic crises pass to Sub-Saharan Africa, (Allen \& Giovannetti, 2011) point out that amongst others, trade is the major conveyer of such shocks. They assert that many of these countries are fragile and have suffered from increased exchange-rate volatility, which has caused high uncertainty and high costs for international trade, however, the magnitude of the shock depends on the degree of the concentration of exports.

The correlation between trade partners and an economy's growth is such a tough discussion with a little theoretical and empirical backings. Because trade partners tend emitting shocks to an economy, there is the need for studies into whether they should be of concern or not. Using data on international trade, (Bastos, 2020) assessed the impact of exposure of Belt and Road economies to trade shocks from China and found that China's trade progress (accession to the WTO) heavily impacted the export performance of Belt and Road economies. Bastos found that the rise in imports of China between 2000 and 2015 lead to a parallel rise in exports of those economies but this effect was mitigated by increased competition from China in export markets. Additionally, it was found that the effects of competition shocks were also relatively stronger in countries that are relatively poorer and geographically closer to China. In a related study analyzing imports and exports separately between China and 18 of its advanced economy partners, (Ahn \& Duval, 2017) indicated large productivity gains from trading with China and a negative employment effect of Chinese imports in exposed country-industries between the mid-1990s and late-2000s.

Using the above as a basis, this paper hypothesizes and intends to empirically determine whether macroeconomic fluctuations in Africa and ASEAN have an influence on the China's trade with them. There is currently no research close in scope to this paper. Thus, neither economic shocks of China on Africa and ASEAN or vise-e-versa has been studied. This work intends to provide empirical findings which other researchers could build on.

\section{DATA AND METHODOLOGY 3.1 Data and sources}

This paper aims at determining whether or not the macroeconomic fluctuations in African and ASEAN countries have an impact on China's trade with them. Data is sourced on Gross Domestic Product (GDP) per capita, Foreign Direct Investment (FDI), inflation and unemployment rates, trade openness (TO) of 30 African and 9 ASEAN partners of China, as well as the geographical distance between China and these countries. The dependent variables are the bilateral trade; imports and exports between China and these partners. Since bilateral trade data between China and its partner countries are mostly not available from the 1990s, this research selects data from 2000 to 2018. Data on all variables except bilateral trade and distance was obtained from the world development indicators (WDI) of the World Bank. Bilateral trade data was extracted from the world integrated trade solutions (WITS) whilst data on geographical distance (in kilometers) was obtained from the Centre d'Études Prospectives et d'Informations Internationales ( CEPII ).

\subsubsection{Variable description}

This research uses the bilateral trade values of China and its trade partners as the dependent variables whilst the independent variables are data from the trade partners. The distance variable represents the distance from China's capital to those of its partners. The intent is to check the direction of the impact of a change in the independent variables on China's trade.

There is certainly a relationship between the consumption trends and changes in individual income as proposed by the Engels curve. Generally, countries with higher economic growth and GDP per capita tend to export more sophisticated goods. Their imports also tend to go with high specifications and standards. Given this, their imports from developing economies mostly tend to be raw materials or semi-finished products. As put by (UNCTAD, 2019), the EXPY (export sophistication) index and GDP per capita are positively correlated.

FDI (inwards) has received a great deal of attention in the past decade as many a study has been conducted to unearth its impacts on the various aspects of an economy. As seen in (Chuang \& Hsu, 2004), there is a strong relationship between international trade and inward FDI. International trade enables countries to access new technologies and information to boost their local industries. These new technologies and other benefits of international trade are used to improve local productivity that intends to make the country's products more competitive internationally. The same opinion is shared by (Aizenman \& Noy, 2005; Dash \& Sharma, 2011; Kurtishi-Kastrati, 2013). A link is also established between inflation and trade openness in (Lane, 1997) where they further advocate for trade openness to be taken seriously in deliberations on inflation. It is noted that inflation causes the prices of goods and services to rise unsteadily. This makes local production costive and reduces export as pricecompetitive imports flood local markets. The high potential of inflation spillovers (shocks) is discussed in 


\section{SJIF Impact Factor 2021: 7.13| ISI I.F.Value:1.241| Journal DOI: 10.36713/epra2016 \\ ISSN: 2455-7838(Online) \\ EPRA International Journal of Research and Development (IJRD)}

(Balcilar \& Bekun, 2020; Ciccarelli \& García, 2015; Jordan, 2016).

International trade could leave various impacts on a country's employment. For developing economies, the influx of imported goods mostly leads to the paralyzing of local industries leading to high unemployment rates. In a "successful export industry", thus an industry that has succeeded in capturing a share in the international market, its employment rate could be dependent on the happenings on the international market. (Fugazza et al., 2014) confirms that the effect of trade on unemployment in an economy depends on the covariance between comparative advantage and sector level labor market frictions.

The conversation of distance and trade has remained strong to date. The improvement in means of transportation and the cargo operations has to a great extent, reduced the impact of distance on trade. (Borchert \& Yotov, 2016) found a reduced effect of distance on trade by $9.34 \%$ for the 69 study countries studies from 1986 to 2006. Further, in assessing the volatility between trade and distance, their results pointed to negative and statistically significant coefficients (Mehl et al., 2019). Other discussion on this subject are held in (Berthelon \& Freund, 2008; Knoll et al., 2018)

This research is underpinned in these economic observations and conclusions whilst its relevance lies in the fact that the majority of research work is focused on how these variables interplay with increased trade volumes of a particular country. That is to say, the focus of this paper is rather how the bilateral trade of a country (China) is affected by the per capita, Foreign Direct Investment (FDI), inflation and unemployment rates, as well as trade openness of its trade partners (Africa and ASEAN).

\subsection{Econometric model}

This work is based on the gravity model as proposed by (Tinbergen, 1962) and seen in (Bergstrand, 1989; Çekyay et al., 2020; Chaney, 2018) amongst other researches. The equation assumes bilateral trade flows $(X)$ to be dependent on the product of the incomes $(E)$ of the two partner countries $\mathrm{i}$ and $\mathrm{j}$, divided by the geographical distance separating them $(D)$. The equation is therefore written as;

$$
X_{i j}=\frac{E_{i} E_{j}}{D_{i j}}
$$

Over the years, gravity has been used in a wide range of study fields and has been given many modifications and alterations. For instance, (Matyas, 1997) proposes a three-way model specification of the gravity model as;

$$
y_{h f t}=\alpha_{0}+\alpha_{h}+\gamma_{f}+\theta_{t}+\beta^{\prime}{ }_{1} x_{h f t}+\beta_{2}^{\prime} x_{h t}+\beta_{3}^{\prime} x_{f t}+\beta^{\prime}{ }_{4} Z_{h f}+u_{h f t}
$$

issues of heterogeneity bias associated with

Of the three dimensions, one is time-specific $\left(\theta_{t}\right)$ whilst the others are time-invariant export and import countryspecific effects $\left(\alpha_{h}\right.$ and $\left.\gamma_{f}\right)$. In their attempt to handle provide the following model incorporating fixed effects.

$$
\mathrm{y}_{\mathrm{hft}}=\alpha_{0}+\alpha_{\mathrm{hf}}+\theta_{\mathrm{t}}+\beta^{\prime}{ }_{1} \mathrm{x}_{\mathrm{hft}}+\beta^{\prime}{ }_{2} \mathrm{x}_{\mathrm{ht}}+\beta^{\prime}{ }_{3} \mathrm{x}_{\mathrm{ft}}+\beta^{\prime}{ }_{4 \mathrm{Z}_{\mathrm{hf}}}+\mathrm{u}_{\mathrm{hf}}
$$

In measuring the trade potential for China's wind energy with the Belt and Road countries, (Leng et al.,
2020) employed a gravity model which took the following form,

$$
\ln E X_{\mathrm{ijt}}=\beta_{0}+\beta_{1} \ln Y_{\mathrm{it}}+\beta_{2} \ln \mathrm{Y}_{\mathrm{jt}}+\beta_{3} \ln \mathrm{DIST}_{\mathrm{ij}}+\mathrm{u}_{\mathrm{ijt}}
$$

where $\ln$ is the natural logarithm of the variables, $\mathrm{EX}_{\mathrm{ijt}}$ is the exports of wind energy products from country $i$ to $j$ in year t. $Y_{i t}$ and $Y_{j t}$ denote the GDP of the exporter and importer countries respectively and DIST $_{\mathrm{ij}}$ is the geographical distance between them.

\subsection{Data estimation challenges.}

In estimating international trade-related data, two major problems are observed to be encountered by many a research which has attracted attention. These are endogeneity and zero trades. Endogeneity refers to the case where the dependent variable in a study is surmised to be correlated with some variables of the error term whereas zero trade is the instance where both partners to trade fail to report figures for some period(s).

Various approaches have been suggested to deal with the estimation challenges. Some of these studies include; (Baier \& Bergstrand, 2007; Liu et al., 2020; Montalbano et al., 2005; Ojo \& Baiyegunhi, 2020). Researchers have suggested several approaches to best handle endogeneity such as; including country-pair fixed effects by (Baier \& Bergstrand, 2007) building on (Wooldridge, 2002). Other approaches include the use 


\section{EPRA International Journal of Research and Development (IJRD)}

of instrumental variables (IVs) as seen in (Bollen \& Bauer, 2004; Dippel et al., 2017; Mehta, 2001; Sajons, 2020). Due to the difficulty in coming by such IVs and the controversies surrounding their use, they are not considered for this work.

The problem is zero trade is most common amongst developing countries' data. A common observation is that for some periods, both parties to trade do no report any values. This makes econometric analysis very challenging although several approaches have been suggested and implemented by some studies. Common methods to resolve this include replacing the unavailable trade with small positive values. This is questionable since the inserted value is not the actual trade for the period and could result in err-some findings. The use of the Heckman selection model; (Jang, 2006; Plümper et al., 2006) and the Poisson (PLM) model; (Krisztin \& Fischer, 2015; Linders et al.,
2009) dominate the econometric technique to deal with zero trades.

For this work, the following is decided; based on the controversies surrounding the use of IVs and other ways to deal with endogeneity, econometric estimators that have strong backgrounds and evidence of treating endogeneity are opted for. Also, country pairs and years with Zero trades are omitted, hence, thirty (30) African countries and nine (9) ASEAN countries are used.

Based on the above, this study tunes the gravity model to obtain the following equation; where "In" is the log form of the variables, "imp and exp" represent the bilateral trade (imports and exports) between China and its partners, $\beta_{1-} \beta_{6}$ represent the independent variables followed by the error term.

$$
\ln i m p / \ln \exp =\beta_{0}+\beta_{1}\left(\ln \text { percap }_{i t}\right)+\beta_{2}\left(\ln T O_{i t}\right)+\beta_{3}\left(\ln F D I_{i t}\right)+\beta_{4}\left(\ln i n f_{i t}\right)+\beta_{5}\left(\ln u e m_{i t}\right)+\beta_{6}\left(\ln \text { dist }_{i t}\right)+\varepsilon_{i t}
$$

Judging from previous studies and the literature gathered, it is expected of the independent variables to take the following signs;

Table 1: variables and expected signs

\begin{tabular}{|c|c|l|}
\hline Variables & $\begin{array}{c}\text { Sign } \\
\text { Imports/ } \\
\text { exports }\end{array}$ & \multicolumn{1}{|c|}{ Note } \\
\hline percap $_{i t}$ & $+/-$ & $\begin{array}{l}\text { An increase in per capita is expected to increase China's imports but } \\
\text { reduce exports to Africa and ASEAN }\end{array}$ \\
\hline$F D I_{i t}$ & $+/-$ & $\begin{array}{l}\text { An increase in FDI is expected to increase China's imports from China } \\
\text { and reduce exports to Africa and ASEAN }\end{array}$ \\
\hline inf $_{\text {it }}$ & $-/+$ & It is expected to reduce China's imports but increase its exports \\
\hline unem $_{i t}$ & $-/+$ & $\begin{array}{l}\text { It is expected to reduce China's imports but increase its exports to } \\
\text { Africa and the ASEAN countries }\end{array}$ \\
\hline TO $_{i t}$ & $+/+$ & $\begin{array}{l}\text { Openness is expected to increase China's imports from and exports to } \\
\text { Africa and ASEAN }\end{array}$ \\
\hline dist $_{i t}$ & $-/-$ & $\begin{array}{l}\text { There is an expectation of high trade between China and countries } \\
\text { closer to it }\end{array}$ \\
\hline
\end{tabular}

\section{EMPIRICAL ESTIMATIONS}

\subsection{Descriptive statistics}

Table 2 presents the descriptive statistics of the variables used for this research. It could be deduced that imports and exports grew at annual average rates of $12.1 \%$ and $13.4 \%$ respectively. The maximum and the minimum for the variables show that there is a wide differential pattern amongst the countries, thus; the presence of heterogeneity amongst the variables. Further, FDI shows the highest growth rate of $22.9 \%$. The table also shows heavy tails (positive values) according to the Kurtosis and that exports and unemployment are mesokurtic $(<3)$. 
SJIF Impact Factor 2021: 7.13| ISI I.F.Value:1.241| Journal DOI: 10.36713/epra2016

ISSN: 2455-7838(Online)

EPRA International Journal of Research and Development (IJRD)

Volume: 6 | Issue: 3 | March 2021

- Peer Reviewed Journal

Table 2: Descriptive statistics

\begin{tabular}{|l|r|r|r|r|r|r|r|r|}
\hline & \multicolumn{1}{|l}{ Inimp } & \multicolumn{1}{l}{ Inexp } & Inpercap & \multicolumn{1}{l}{ InTO } & InFDI & Ininf & Inuem & \multicolumn{1}{l}{ Indist } \\
\hline Mean & 12.106 & 13.393 & 7.286 & 4.280 & 22.926 & 4.183 & 1.567 & 9.010 \\
\hline Median & 12.084 & 13.378 & 7.104 & 4.215 & 22.797 & 4.168 & 1.723 & 9.221 \\
\hline Max. & 17.976 & 18.247 & 11.076 & 6.081 & 25.350 & 6.353 & 3.511 & 9.423 \\
\hline Min. & -6.900 & 5.646 & 4.732 & 3.031 & 16.357 & -4.605 & -1.298 & 7.754 \\
\hline Std. Dev. & 3.336 & 2.244 & 1.272 & 0.512 & 0.473 & 0.353 & 0.959 & 0.504 \\
\hline Skewness & -0.985 & -0.140 & 0.636 & 0.686 & -2.575 & -20.336 & -0.390 & -1.272 \\
\hline Kurtosis & 6.077 & 2.760 & 3.137 & 4.133 & 60.889 & 523.939 & 2.722 & 3.032 \\
\hline Jarque-Bera & 412.161 & 4.196 & 50.592 & 97.837 & 104285.9 & 8429834 & 21.166 & 199.731 \\
\hline Prob. & 0.000 & 0.127 & 0.000 & 0.000 & 0.000 & 0.000 & 0.000 & 0.000 \\
\hline Sum & 8970.831 & 9924.544 & 5398.955 & 3171.526 & 16987.93 & 3099.301 & 1161.392 & 6676.22 \\
\hline Sum Sq. Dev. & 8233.422 & 3724.815 & 1196.919 & 193.8365 & 165.412 & 92.1073 & 680.4116 & 188.3239 \\
\hline Obs & 741 & 741 & 741 & 741 & 741 & 741 & 741 & 741 \\
\hline
\end{tabular}

4

\section{.2 Correlation matrix}

A positive correlation of $0.564,0.380$, and 0.452 all significant at $1 \%$ is recorded between imports and per capita, FDI, and trade openness respectively. However, negatives of -0.085 and -0.125 are recorded for inflation and distance. This tells that there is a strong positive relation between China's imports and some economic indicators of its African and ASEAN trade partners. GDP per capita, FDI and trade openness still prove to have strong positive relationships at $1 \%$ significance whilst inflation, unemployment and bilateral distance report negative correlations.

Table 3: Correlation matrix

\begin{tabular}{|l|r|r|r|l|l|l|l|l|}
\hline Prob. & Inimp & Inexp & Inpercap & InTO & InFDI & Ininf & Inuem & Indist \\
\hline Inimp & 1.000 & & & & & & & \\
\hline Inexp & $0.761^{* * *}$ & 1.000 & & & & & & \\
\hline Inpercap & $0.564^{* * *}$ & $0.541^{* * *}$ & 1.000 & & & & & \\
\hline InTO & $0.452^{* * *}$ & $0.344^{* * *}$ & $0.571^{* * *}$ & 1.000 & & & & \\
\hline InFDI & $0.380^{* * *}$ & $0.491^{* * *}$ & $0.394^{* * *}$ & $0.372^{* * *}$ & 1.000 & & & \\
\hline Ininf & $-0.085^{* *}$ & $-0.063^{*}$ & $-0.108^{* *}$ & $-0.088^{* *}$ & 0.016 & 1.000 & & \\
\hline Inuem & 0.054 & -0.057 & $0.345^{* * *}$ & 0.054 & $-0.073^{* *}$ & 0.004 & 1.000 & \\
\hline Indist & $-0.125^{* * *}$ & $-0.258^{* * *}$ & 0.014 & 0.021 & $-0.129^{* * *}$ & 0.001 & $0.105^{* *}$ & 1.000 \\
\hline
\end{tabular}

Note: ${ }^{* * *}, * *$, and $*$ indicate $1 \%, 5 \%$ and $10 \%$ significance levels respectively 


\section{SJIF Impact Factor 2021: 7.13| ISI I.F.Value:1.241| Journal DOI: 10.36713/epra2016 \\ ISSN: 2455-7838(Online) \\ EPRA International Journal of Research and Development (IJRD)}

Volume: 6 | Issue: 3 | March $2021 \quad$ - Peer Reviewed Journal

Table 4: Estimation results

\begin{tabular}{|c|c|c|c|c|}
\hline \multirow[b]{2}{*}{ Variable } & \multicolumn{2}{|c|}{ Imports } & \multicolumn{2}{|c|}{ Exports } \\
\hline & PCSE & MVR & PCSE & MVR \\
\hline lnpercap & $\begin{array}{c}1.217^{* * *} \\
(8.81)\end{array}$ & $\begin{array}{c}1.217^{* * *} \\
(11.53)\end{array}$ & $\begin{array}{c}0.946^{* * *} \\
(9.20)\end{array}$ & $\begin{array}{c}0.496^{* * *} \\
(14.31)\end{array}$ \\
\hline $\ln \mathrm{TO}$ & $\begin{array}{c}0.955^{* * *} \\
(6.14)\end{array}$ & $\begin{array}{c}0.955^{* * *} \\
(4.02)\end{array}$ & $\begin{array}{l}-0.189 \\
(-1.44)\end{array}$ & $\begin{array}{l}-0.189 \\
(-1.27)\end{array}$ \\
\hline $\operatorname{lnFDI}$ & $\begin{array}{c}0.867^{* *} \\
(2.80)\end{array}$ & $\begin{array}{c}0.867^{* * * *} \\
(3.69)\end{array}$ & $\begin{array}{c}1.206^{* * *} \\
(4.68)\end{array}$ & $\begin{array}{c}1.206^{* * *} \\
(8.20)\end{array}$ \\
\hline lninf & $\begin{array}{l}-0.215 \\
(-0.46)\end{array}$ & $\begin{array}{l}-0.215 \\
(-0.78)\end{array}$ & $\begin{array}{c}-0.074 \\
(-0.28)\end{array}$ & $\begin{array}{c}-0.074 \\
(-0.43)\end{array}$ \\
\hline lnuem & $\begin{array}{c}-0.327^{* *} \\
(-2.90)\end{array}$ & $\begin{array}{c}-0.327^{* *} \\
(-2.91)\end{array}$ & $\begin{array}{c}-0.466^{* * *} \\
(-6.91)\end{array}$ & $\begin{array}{c}-0.466^{* * *} \\
(-6.63)\end{array}$ \\
\hline lndist & $\begin{array}{c}-0.717^{* * *} \\
(-10.59)\end{array}$ & $\begin{array}{c}-0.717^{* * *} \\
(-3.69)\end{array}$ & $\begin{array}{c}-0.939 * * * \\
(-26.63)\end{array}$ & $\begin{array}{c}-0.939 * * * \\
(-7.72)\end{array}$ \\
\hline Intercept & $\begin{array}{c}-12.842^{* *} \\
(-1.93)\end{array}$ & $\begin{array}{c}-12.842^{* *} \\
(-2.28)\end{array}$ & $\begin{array}{c}-10.833^{*} \\
(-1.90)\end{array}$ & $\begin{array}{c}-10.833^{* *} \\
(-3.07)\end{array}$ \\
\hline Obs & \multicolumn{2}{|c|}{741} & \multicolumn{2}{|c|}{741} \\
\hline $\begin{array}{l}\mathrm{R}^{2} \\
\text { F-Stats } \\
\text { Wald chi test }\end{array}$ & $\begin{array}{c}0.385 \\
- \\
408.20^{* * *}\end{array}$ & $\begin{array}{c}0.385 \\
76.647^{* * *} \\
-\end{array}$ & $\begin{array}{c}0.467 \\
- \\
2551.43^{* * *}\end{array}$ & $\begin{array}{c}0.467 \\
107.140^{* * *} \\
-\end{array}$ \\
\hline
\end{tabular}

Note: $* * * * *$, and $*$ indicate $1 \%, 5 \%$ and $10 \%$ significance levels respectively

The main regression estimator; PCSE, and the robust check result produced results of great similarity. The results indicate a strong positive relationship between per capita and imports as well as exports which is a mix of the research expectations. The results show that a percentage increase in per capita could lead to a $1.217 \%$ change in imports. This result is further confirmed by the robust estimator. This could be expatiated as; an increase in per capita represents an improvement in the general economy including industrial output. This could therefore cause an increase in China's imports from these developing economies. Further, the results indicate that exports are expected to increase by 0.946 upon a percentage increase in per capita. On the contrary, the study expected that an increase in per capita of China's trade partners will cause them to shift demand to products from Europe and America that are expensive than those of China, hence, a negative sign was anticipated.

Trade openness is also shown to positively impact imports just as expected. A percentage increase in the openness of Chinese partners is expected to increase its imports from them by $0.955 \%$. However, the results tell that an increase in the level of trade openness could impact China's exports from these countries by -0.189 . The point is that the openness variable here is not that of the study country (China) but rather, its trade partners. An explanation therefore could be given that developing countries will tend to import less from China as they open up to trade.

This study also points out that the FDI of trade partners could positively impact on imports of a country. It is seen that an increase in FDI of China's partners leads to a $0.867 \%$ and $1.206 \%$ increase in imports and exports respectively. A justification could be made as; an increased FDI translates into growth and quality of industrial output (Sen, 2008; UNCTAD, 2015). This could therefore increase China's imports from these economies. Again, as observed in (Hakizimana, 2015), FDI inflows positively impact GDP per capita which intends increases the consumption of citizens. This could justify the reason for China's increased exports to these upon an increase in their FDI. The inflation rates of China's partners are reported to have negative impacts on China's trade. The estimations point that a percentage increase in inflation reduces $(-0.215)$ imports whilst that of exports is by -0.74 although these impacts do not carry any significance levels.

Also, an increase in the unemployment rate of China's trade partners impacts China's imports by $0.317 \%$ as well as exports by $-0.466 \%$. Practically, high unemployment rates of these economies could be caused by "low-grade" industrialization that will render its exports unattractive, hence reduced imports by China. The possibility of an increase in 


\section{SJIF Impact Factor 2021: 7.13| ISI I.F.Value:1.241| Journal DOI: 10.36713/epra2016 \\ ISSN: 2455-7838(Online) \\ EPRA International Journal of Research and Development (IJRD)}

Volume: 6 | Issue: 3 | March 2021

- Peer Reviewed Journal

unemployment of developing economies leading to reduced imports (in this case, exports from China) could be grounded in other macroeconomic indicators such as inflation and exchange rates in those countries. For instance, an increase in unemployment coupled with high exchange rates could result in a reduction in imports by an economy.

The coefficients of the geographical distance variable show negative with strong statistical significance for both imports and exports. This follows suit of the gravity espectation that countries will trade much with closer partners. In this scenario, it could be interpreted as; the wider the distance, the lesser China trades with a partner. Considering the two groups of countries in this study, thus; Africa and ASEAN countries, the results support recent arguments on why the ASEAN region is now China's top trade partner (Feiteng, 2020).

\section{CONCLUSION}

There have been countless studies on how macroeconomic indicators impact a country's trade but there are a few on how these indicators tend to impact trade partners, thus external economic shocks. Based on the concept of economic shocks, this study assessed specifically, the impact of macroeconomic fluctuations of African and ASEAN countries on China's bilateral trade (imports and exports) with them.

Data was obtained on the bilateral trade of China as well as GDP per capita, trade openness, FDI, inflation, and exchange rates of 30 African and 9 ASEAN countries from 2000 to 2018. The gravity model was employed for the estimations and the panel corrected standard errors (PCSE) was the main estimator whilst multivariate regressor in Stata 14 (mvreg command) acted as a robust check.

Results from the estimations indicated that an increase in the per capita of China's trade partners leads to both an increase in China's imports from as well as its exports to them. This confirms other studies including (Obeng, 2018) and is an indication of how acceptable Chinese products have become especially in developing economies. Trade openness is reported to increase China's imports from its partners but reduce exports to them. Again, an increase in FDI inflows into China's trade partners benefits both channels of trade, thus, it leads to an increase in both imports and exports. The inflation and unemployment rate of partner countries are both expected to reduce China's trade with its trade partners.

This study's approach to measuring economic shocks is yet to be further explored by other researchers. It lays the basis for studies into how trade partners' economic situations affect each other and how the gravity model comes into play.

\section{REFERENCES}

1. Adekunle, B., \& Monika, K. (2017). Trading with China: How can Africa Benefit?

2. Ahn, J., \& Duval, R. (2017). Trading with China: Productivity Gains, Job Losses (17/122). https://papers.ssrn.com/sol3/papers.cfm?abstract_i $d=3014033$

3. Aizenman, J., \& Noy, I. (2005). FDI and TradeTwo Way Linkages? (No. 11403; Issue 9). http://www.ncbi.nlm.nih.gov/pubmed/810049\%0Ah ttp://doi.wiley.com/10.1002/anie.197505391\%0A

4. Allen, F., \& Giovannetti, G. (2011). The effects of the financial crisis on Sub-Saharan Africa. Review of Development Finance, 1(1), 1-27. https://doi.org/10.1016/j.rdf.2010.10.002

5. ASEAN. (2016). The Asean Declaration (Bangkok Declaration) Bangkok, 8 August 1967. http://asean.org/the-asean-declaration-bangkokdeclaration-bangkok-8-august-1967/

6. Baier, S. L., \& Bergstrand, J. H. (2007). Do free trade agreements actually increase members' international trade? Journal of International Economics, 71(1), 72-95. https://doi.org/10.1016/j.jinteco.2006.02.005

7. Balassa, B. (1983). Policy responses to external shocks in sub-Saharan African countries. Journal of Policy Modeling, 5(1), 75-105. https://doi.org/10.1016/0161-8938(83)90023-6

8. Balcilar, M., \& Bekun, F. V. (2020). Spillover dynamics across price inflation and selected agricultural commodity prices. Journal of Economic Structures, 9(1). https://doi.org/10.1186/s40008-020-0180-0

9. Baliamoune-Lutz, M. (2011). Growth by destination (where you export matters): Trade with China and growth in African countries. African Development Review, 23(2), 202-218. https://ideas.repec.org/a/adb/adbadr/545.html

10. Bastos, P. (2020). Exposure of belt and road economies to China trade shocks. Journal of Development Economics, 145(February), 102474. https://doi.org/10.1016/j.jdeveco.2020.102474

11. Bello, K. M., \& Akinbobola, T. . (2020). Trade openness, economic growth and poverty reduction in ECOWAS countries: (A panel causality).

12. Ben-David, D. (1993). Equalizing Exchange: Trade Liberalization and Income Convergence. The Quarterly Journal of Economics, 108(3), 653-679. https://doi.org/10.2307/2118404

13. Bergstrand, J. H. (1989). The Generalized Gravity Equation, Monopolistic Competition, and the Factor-Proportions Theory in International Trade. Review of Economics and Statistics, 71(1), 143153.

14. Berthelon, M., \& Freund, C. (2008). On the conservation of distance in international trade. 


\section{EPRA International Journal of Research and Development (IJRD)}

Journal of International Economics, 75(2), 310 320. https://doi.org/10.1016/j.jinteco.2007.12.005

15. Bollen, K. A., \& Bauer, D. J. (2004). Automating the Selection of Model-Implied Instrumental Variables. Sociological Methods and Research, 32(4), 425-452. https://doi.org/10.1177/0049124103260341

16. Borchert, I., \& Yotov, Y. V. (2016). Distance, Globalization, and International Trade Ingo Borchert Distance , Globalization, and International Trade Abstract. CESifo Working Papers, 6275.

17. Brautigam, D., Hwang, J., Link, J., \& Acker, K. (2020). Chinese Loans to Africa Database. https://chinaafricaloandata.org/

18. Briggs, A. M., Shiffman, J., Shawar, Y. R., Akesson, K., Ali, N., \& Woolf, A. D. (2020). Global health policy in the 21st century: Challenges and opportunities to arrest the global disability burden from musculoskeletal health conditions. Best Practice and Research: Clinical Rheumatology, xxxx, 101549. https://doi.org/10.1016/j.berh.2020.101549

19. Çekyay, B., Kabak, Ö., Ülengin, F., Ulengin, B., Toktaş Palut, P., \& Özaydın, Ö. (2020). A multicommodity network flow and gravity model integration for analyzing impact of road transport quotas on international trade. Research in Transportation Economics, 80(November 2019). https://doi.org/10.1016/j.retrec.2020.100816

20. Chaney, T. (2018). The gravity equation in international trade: An explanation. Journal of Political Economy, 126(1), 150-177. https://doi.org/10.1086/694292

21. Chang, R., Kaltani, L., \& Loayza, N. V. (2009). Openness can be good for growth: the role of policy complementarities. Journal of Development Economics, 90(1), 33-49. https://ideas.repec.org/a/eee/deveco/v90y2009ilp3 3-49.html

22. Chen, K., Xu, S., \& Haralambides, H. (2020). Determining hub port locations and feeder network designs: The case of China-West Africa trade. Transport Policy, 86, 9-22. https://doi.org/10.1016/j.tranpol.2019.12.002

23. Cheng, I.-H., \& Wall, H. J. (2005). Controlling for Heterogeneity in Gravity Models of Trade and $\begin{array}{lll}\text { Integration } & \text { (No. }\end{array}$ https://doi.org/10.20955/r.87.49-64

24. Chuang, Y. C., \& Hsu, P. F. (2004). FDI, trade and spillover efficiency: Evidence from China's manufacturing sector. Applied Economics, 36(10), 1103-1115. https://doi.org/10.1080/0003684042000246812

25. Ciccarelli, M., \& García, J. A. (2015). International spillovers in inflation expectations (No. 1857; Issue 1857).

26. Dash, R. K., \& Sharma, C. (2011). FDI, trade, and growth dynamics: New evidence from the postreform India. International Trade Journal, 25(2),
233-266.

https://doi.org/10.1080/08853908.2011.554787

27. Dippel, C., Gold, R., Heblich, S., \& Pinto, R. (2017). Instrumental Variables and Causal Mechanisms: Unpacking the Effect of Trade on Workers and Voters. National Bureau of Economic Research Working Paper Series, 23209. https://www.nber.org/papers/w23209.pdf

28. Dollar, D., \& Kraay, A. (2004). Growth is Good for the Poor. Growth, Inequality, and Poverty: Prospects for Pro-Poor Economic Development, 195-225. https://doi.org/10.1093/0199268657.003.0002

29. Dunford, M., \& Qi, B. (2020). Global reset: COVID-19, systemic rivalry and the global order. In Research in Globalization (Vol. 2). Elsevier Ltd. https://doi.org/10.1016/j.resglo.2020.100021

30. Easterly, W., \& Kraay, A. (1999). Small States, Small Problems? (No. 2139). https://ideas.repec.org/p/wbk/wbrwps/2139.html

31. Federici, A., \& Montalbano, P. (2010). Does Trade Openness Make Countries Vulnerable? (3/10; Issue January). https://ideas.repec.org/p/saq/wpaper/310.html

32. Feiteng, Z. (2020). China-ASEAN trade growth is shored up by solid foundation. https://WWW.globaltimes.cn/content/1200840.shtml

33. Flick, K. E., \& Kemburi, K. M. (2012). ASEANChina Free Trade Area Challenges, Opportunities and the Road Ahead. https://www.rsis.edu.sg/wpcontent/uploads/2000/01/Monograph22.pdf

34. Frankel, J. A., \& Romer, D. (1999). Does Trade Cause Growth? American Economic Review, 89(3), 379-399. https://eml.berkeley.edu/ dromer/papers/AER_Jun e99.pdf

35. Fugazza, M., Carrère, C., \& Olarreaga, M. (2014). TRADE IN UNEMPLOYMENT (No. 64; IsSue 64).

36. Guillaumont, P. (2000). On the Economic Vulnerability of Low Income Countries (No. 200102; Issue 200016). http://econpapers.repec.org/RePEc:cdi:wpaper:143

37. Haddad, M., Lim, J. J., Pancaro, C., \& Saborowski, C. (2013). Trade openness reduces growth volatility when countries are well diversified. Canadian Journal of Economics, 46(2), 765-790. https://doi.org/10.1111/caje.12031

38. Hakizimana, J. (2015). The Relationship between Foreign Direct Investment (FDI) and GDP Per Capita in Rwanda. SSRN Electronic Journal. https://doi.org/10.2139/ssrn.2598413

39. Huang, C. L. (2020). International stock market comovements following US financial globalization. International Review of Economics and Finance, 69 , https://doi.org/10.1016/j.iref.2020.06.009 788-814.

40. Huchet-bourdon, M., Mouël, C. Le, \& Vijil, M. (2018). The relationship between trade openness and economic growth: Some new insights on the 


\section{EPRA International Journal of Research and Development (IJRD)}

openness measurement issue. World Economy, 41(1), 59-76. https://doi.org/10.1111/twec. 12586

41. Jang, H. S. (2006). Contracting out parks and recreation services: Correcting for selection bias using a Heckman selection model. International Journal of Public Administration, 29(10-11), 799818. https://doi.org/10.1080/01900690600770488

42. Jordan, T. J. (2016). The impact of international spillovers on $S$ wiss inflation and the exchange rate. Journal of International Money and Finance, 68, 262-265.

https://doi.org/10.1016/j.jimonfin.2016.02.005

43. Khobai, H., Kolisi, N., \& Moyo, C. (2018). The Relationship Between Trade Openness and Economic Growth: The Case of Ghana and Nigeria. International Journal of Economics and Financial Issues, Econjournals, 8(1), 77-82. https://ideas.repec.org/a/eco/journ1/2018-0110.html\#: : text=The results further showed that,insignificant effect on economic growth.

44. Knoll, S., Padula, A. D., Barcellos, J. O. J., Pumi, G., Zhou, S., \& Zhong, F. (2018). The role of distance on international commerce: the impact on Sino-Brazilian beef trade. Journal of Agribusiness in Developing and Emerging Economies, 8(4), 693-711. https://doi.org/10.1108/JADEE-04-20170041

45. Krisztin, T., \& Fischer, M. M. (2015). The Gravity Model for International Trade: Specification and Estimation Issues. Spatial Economic Analysis, 10(4), 451-470. https://doi.org/10.1080/17421772.2015.1076575

46. Kurtishi-Kastrati, S. (2013). The Effects of Foreign Direct Investments for Host Country's Economy. American University of the Middle East, 5(1). http://www.ejist.ro/files/pdf/369.pdf

47. Lane, P. R. (1997). Inflation in open economies. Journal of International Economics, 42(3-4), 327347. 1996(96)01442-0

48. Large, D. (2008). Beyond "dragon in the bush": the study of China-Africa relations. African Affairs, 107(426), https://doi.org/10.1093/afraf/adm069

49. Leng, Z., Shuai, J., Sun, H., Shi, Z., \& Wang, Z. (2020). Do China's wind energy products have potentials for trade with the "Belt and Road" countries? -- A gravity model approach. Energy Policy, $\quad 137$ (December), 111172 https://doi.org/10.1016/j.enpol.2019.111172

50. Ligon, E. A. (2003). Measuring Vulnerability. Economic Journal, 113(486), 95-102.

51. Linders, G.-J., van Oort, F., \& Burger, M. (2009). On the Specification of the Gravity Model of Trade: Zeros, Excess Zeros and Zero-inflated Estimation. Spatial Economic Analysis, 4(2), 167190. https://doi.org/10.1080/17421770902834327

52. Liu, W., Shao, X., De Sisto, M., \& Li, W. H. (2020). A new approach for addressing endogeneity issues in the relationship between corporate social responsibility and corporate financial performance. Finance Research Letters. https://doi.org/10.1016/j.frl.2020.101623

53. Locke, B., \& Aguiar, F. (2018). Chinese Engagement in Africa Understanding the Risks and Opportunities for the European Union. https://Www.bic-rhr.com/sites/default/files/inlinefiles/PDF- Chinese Engagement in Africa.pdf

54. Matyas, L. (1997). Proper Econometric Specification of the Gravity Model. The World Economy, 20(3), 363-368. https://doi.org/10.1111/1467-9701.00074

55. Medina, A. F. (2020). ASEAN Overtakes EU to Become China's Top Trading Partner in Q1 2020. https://WWW.aseanbriefing.com/news/aseanovertakes-eu-become-chinas-top-trading-partnerq1-2020/

56. Mehl, A., Schmitz, M., \& Tille, C. (2019). Distance(s) and the Volatility of International Trade(s). ECB Working Paper, 2252.

57. Mehta, P. D. (2001). Control Variable in Research. International Encyclopedia of the Social \& Behavioral Sciences, 2727-2730. https://doi.org/10.1016/b0-08-043076-7/00734-8

58. Montalbano, P. (2016). Essays on Trade Openness and Vulnerability to Poverty. University of Sussex, $U K$.

59. Montalbano, P., Federici, A., Triulzi, U., \& Pietrobelli, $C$. (2005). Trade openness and vulnerability in Central and Eastern Europe (2005/43). http://hdl.handle.net/10419/63477

60. Moyo, C., \& Khobai, H. (2018). Trade Openness and Economic Growth in SADC Countries. Economia Internazionale / International Economics, 71(4), 417-436.

61. Nduka, E. K., Chukwu, J. O., Ugbor, K. I., \& Nwakaire, O. N. (2013). Trade openness and economic growth: A comparative analysis of the pre and post structural adjustment programme (Sap) Periods in Nigeria. Asian Journal of Business and Economics, 3(3), 1-12.

62. Nowak, W. (2015). China's Development Aid Strategies. Chinese Business Review, 11(4), 201209. https://doi.org/10.17265/1537$1506 / 2015.04 .004$

63. Nowak, W. (2016). China-Africa and India-Africa trade in the years 2000-2014. Procedia Economics and Finance, 39(November 2015), 140-146. https://doi.org/10.1016/s2212-5671(16)30261-1

64. Obeng, M. K. M. (2018). Rational or Irrational? Understanding the Uptake of "Made-in-China" Products. Asian Ethnicity, 20(1), 103-127. https://doi.org/10.1080/14631369.2018.1548266

65. Obuah, E., \& Alabama, A. (2012). Trade between China and Africa: Trends, Changes, and Challenges. International Journal of China Marketing, 2(2), 74-88.

66. OECD. (2015). OECD Economic Outlook. https://www.oecd-ilibrary.org/economics/oecdeconomic-outlook-volume-2015-issue- 


\section{EPRA International Journal of Research and Development (IJRD)}

2_eco_outlook-v2015-2-en

67. Ojo, T. ., \& Baiyegunhi, L. J. S. (2020). Impact of climate change adaptation strategies on rice productivity in South-west, Nigeria: An endogeneity corrected stochastic frontier model. Science of The Total Environment, 745(25), 141151.

https://doi.org/10.1016/j.scitotenv.2020.141151

68. Olufemi, S. (2004). Trade Openness and Economic Growth in Nigeria: Further Evidence on the Causality Issue. South African Journal of Economic and Management Sciences, 7(2), 299315. https://ssrn.com/abstract $=3510419$

69. Plümper, T., Schneider, C. J., \& Troeger, V. E. (2006). The politics of EU eastern enlargement: Evidence from a Heckman selection model. British Journal of Political Science, 36(1), 17-38. https://doi.org/10.1017/S0007123406000020

70. Sachs, J. D., \& Warner, A. M. (1995). Natural Resource Abundance and Economic Growth (No. 5398).

https://ideas.repec.org/p/nbr/nberwo/5398.html

71. Sajons, G. B. (2020). Estimating the causal effect of measured endogenous variables: $A$ tutorial on experimentally randomized instrumental variables. Leadership Quarterly, 31(5), 101348. https://doi.org/10.1016/j.leaqua.2019.101348

72. Savrul, M., \& Onsekiz, C. (2015). The Effect of Globalization on International Trade: The Black Sea Economic Cooperation Case. 88-94.

73. Sen, K. (2008). Trade, FDI and industrial transformation in India. https://crawford.anu.edu.au/acde/events/past/tradea ndinvestment/papers/Sen.pdf

74. Silajdzic, S., \& Mehic, E. (2018). Trade Openness and Economic Growth: Empirical Evidence from Transition Economies. Trade and Global Market. https://doi.org/10.5772/intechopen. 75812

75. Tarim, E. (2010). Two Waves of Globalization in the Istanbul Stock Exchange since 1985 and the Evolution of the Domestic Retail Investor. Competition \& Change, 14(3-4), 343-362. https://doi.org/10.1179/102452910x128377036155 35

76. Tight, M. (2019). Globalization and internationalization as frameworks for higher education research. Research Papers in Education,
00(00),

$1-23$. https://doi.org/10.1080/02671522.2019.1633560

77. Tinbergen, J. (1962). Shaping the World Economy: Suggestions for an International Economic Policy. Twentieth Century Fund.

78. UN. (2019). World Economic Situation and Prospects 2019. https://www.un.org/development/desa/dpad/wpcontent/uploads/sites/45/WESP2019_BOOK-CH33-africa-en.pdf

79. UNCTAD. (2015). Impact of Trade and FDI Policies on Industrial Development in South Asia.

80. UNCTAD. (2019). Key Statistics and Trends in International Trade 2018.

81. Vamvakidis, A. (2002). How Robust Is the Growth-Openness Connection? Historical Evidence. Journal of Economic Growth, 7(1), 5780.

https://ideas.repec.org/a/kap/jecgro/v7y2002i1p5780.html

82. Vlastou, I. (2010). Forcing Africa to open up to trade: Is it worth it? The Journal of Developing Areas, 44(1), 25-39. https://doi.org/10.1353/jda.0.0086

83. Webb, R., Vulliamy, G., Sarja, A., \& Hämäläinen, $S$. (2006). Globalization and leadership and management: A comparative analysis of primary schools in England and Finland. Research Papers in Education, 21(4), 407-432. https://doi.org/10.1080/02671520600942420

84. Wooldridge, J. M. (2002). Econometric Analysis of Cross Section and Panel Data. MIT Press. https://mitpress.mit.edu/books/econometricanalysis-cross-section-and-panel-data-secondedition

85. Yeboah, O., Naanwaad, C., Saleem, S., \& Akuffo, A. (2012). Effects of Trade Openness on Economic Growth: The Case of African Countries. The Southern Agricultural Economics Association, 124.

86. Yin, H., Du, Z., \& Zhang, L. (2018). Assessing the gains and vulnerability of free trade: $A$ counterfactual analysis of Macau. Economic Modelling, 70(October), 147-158. https://doi.org/10.1016/j.econmod.2017.10.019 


\section{APPENDIX}

List of countries in this research

\begin{tabular}{|c|c|c|}
\hline \multicolumn{2}{|c|}{ Africa } & ASEAN \\
\hline Algeria & Kenya & Cambodia \\
\hline Angola & Madagascar & Indonesia \\
\hline Benin & Malawi & Malaysia \\
\hline Botswana & Mali & Philippines \\
\hline Burkina Faso & Mauritania & Thailand \\
\hline Burundi & Mauritius & Vietnam \\
\hline Cote d'Ivoire & Morocco & \\
\hline Cameroon & Niger & \\
\hline Chad & Nigeria & \\
\hline Congo & Senegal & \\
\hline Dem. Rep. Congo & South Africa & \\
\hline Egypt & Togo & \\
\hline Gabon & Tunisia & \\
\hline Gambia & Uganda & Tanzania \\
\hline Ghana & & \\
\hline
\end{tabular}

